\title{
Teaching Effective Listening Skills to Information Systems Majors
}

\author{
Janette Moody \\ The Citadel, Charleston, SC USA
}

moodyi@citadet.edu

\begin{abstract}
Information systems (IS) professionals have consistently expressed the need for good communication skills in IS graduates and universities have responded by providing communication components within their curriculum and coursework. However, the typical understanding and execution of communication skills revolve around teaching presentation skills. While presentation skills are important components of communication, the communication skill of effective listening is of equal importance for information technology professionals. In fact, this skill is essential in the information requirements stage of systems development when the end-user is required to work with the IS professional in deriving the basics of the new system to be developed. This paper describes how the teaching of effective listening skills can be incorporated into a variety of IS courses and offers some exercises and techniques.
\end{abstract}

Keywords: communication skills, listening, information systems professionals, experiential learning

\section{Introduction}

Both academic and practitioner literature are replete with the call for improved communications skills in Information Technology (IT) professionals. The skill is especially important in the context of IT project management situations when leadership, team building and negotiation skills are called into play (Vitiello, 2001). In response, various communication components have been suggested and incorporated into the IT curriculum (Janczewski, 2001). The focus of the communication components in the IT curriculum has been on presentation skills (Janczewski, 2001). Presentation skills can address the problem of end-users having difficulty understanding IT professionals (Hutinski, Vrcek, \& Bubas, 2001).

While presentation skills are vital for conveying the finished product to the ultimate end-users, the communication skill required for determining the information requirements of the finished product are equally, if not more, important. Numerous studies have indicated that re-working unclear information systems requirements is the most expensive part of a project. The communication skill required in this and other sections of the systems development life cycle is the skill of listening. This paper examines some of the barriers to, and skills needed for, effective listening, and provides some classroom exercises that can be used to improve these skills.

\section{Barriers to Effective Listening}

Material published as part of these proceedings, either on-line or in print, is copyrighted by Informing Science. Permission to make digital or paper copy of part or all of these works for personal or classroom use is granted without fee provided that the copies are not made or distributed for profit or commercial advantage AND that copies 1) bear this notice in full and 2) give the full citation on the first page. It is permissible to abstract these works so long as credit is given. To copy in all other cases or to republish or to post on a server or to redistribute to lists requires specific permission from the publisher at Publister@intormingscience.org
There are numerous barriers to effective listening. One of the most fundamental barriers is the misassumption that hearing is listening. However, hearing is the physical act of receiving and processing sound waves that strike the eardrums, and thereby is a passive process. Listening, on the other hand, is an active process that interprets and assigns meaning to those sound waves (Ober, 2001). 
In addition, there is the barrier created by the fact that a listener can think much more quickly than the other person can talk. It has been suggested that we think at 1,000-3,000 words per minute but listen at 125-400 words per minute (HighGain, 2000), so boredom and impatience come quickly. This results in another barrier which is that the listener not only has the speaker's voice with which to contend, but also has an internal voice that keeps up a simultaneous dialog of critiquing, analyzing, and judging what is being heard (Krisco, 1997).

The unskilled listener's automatic response is to be a reactive listener. A reactive listener uses a variety of filters that focus on what the listener already knows, latching onto the familiar and missing much of the new information. Thus, the speaker's information is being screened through a variety of listener reactive filters such as "I've heard this before", "What's the point here?", "This is just like.....", "What's wrong or missing?", etc. (Krisco, 1997, p. 78). These filters create mental barriers to receiving the incoming information in the form it was intended and interfere with the listener gaining new information. As a result, a lot of listening time is spent planning rebuttals rather than listening. Finally, physical distractions such as noise, activity, and temperature can further hinder a listener's ability to fully grasp what the speaker is trying to convey (Ober, 2001).

\section{Effective Listening Skills}

Fortunately, listening skills can be improved through training (Ober, 2001). The goal of the training is to become an affirmative listener (Krisco, 1997). An affirmative listener listens for new information rather than only for confirmation of what he already knows. Listening skill training for IT professionals should address each of the barriers noted above. Participants can share with the class their experiences of particularly challenging "listening" situations, both professional and personal, in order to illustrate the normal, untrained ways of listening. Identifying the listening barrier(s) present in those situations can be used as preparation for a discussion of the ways to overcome those barriers. The first step towards improving listening is becoming aware of the need to improve. This awareness can be heightened by the exercises noted in the third section of this paper. Identifying the importance of effective listening and contrasting it with the unconscious way that most people listen will set the stage for the listening training exercises.

To combat the barrier of boredom and impatience, IT professionals must remind themselves of why they are listening in the first place. In the information requirements determination stage, where the majority of communication problems arise (Hutinski, Vrcek, \& Bubas, 2001), the IT professional is trying to gain domain knowledge, most of which is new information. Reminding oneself of the importance of this phase and the potential downstream problems that can be avoided by effective listening, should provide an incentive to overlook what the IT listener may perceive as the speaker's unpolished delivery or unfamiliarity with technical terms. The barrier of reactive filters can be attacked once the listener is conscious of these filters, and he can then move from "listening to" (reactive listener) to "listening for" (affirmative listener) new information and ideas ((Krisco, 1997, p. 80).

In addition to these mental barriers, the barrier of physical distractions must be addressed. The goal is to eliminate physical distractions by holding the meeting in a place that will preclude telephone interruptions, drop-in co-workers, and other activities that are not part of the meeting. When these eliminations are not possible, then the listener should be aware of the barriers and work even harder at concentrating on what the speaker is presenting by listening for the content and its applicability to the situation at hand.

Finally, students need to be made aware of effective listening practices. Effective listeners do the following (Locker and Kaczmarek, 2001,pg. 336-340):

- Focus on the substance of what is being said, not its delivery

- Look for what can be learned that is new

- Maintain good eye contact 
- Paraphrase the content when appropriate

- Ask for information and clarification

- Do not interrupt

\section{Classroom Exercises for Developing Effective Listening Skills}

Various exercises can be used to increase awareness of the need for improved listening skills. Before students are told about the listening pitfalls and good listening techniques discussed above, they are directed to take an online listening self-assessment at http://WwW.highgain.com/SELF/index.php3.

Next, students participate in an exercise that reveals the tendency of listeners to think they have heard words they did not hear. Based on Roediger and McDermott's (1995) research, lists of associated words are read aloud to students (example: thread, pin eye, sewing, sharp, point, prick, thimble, haystack, thorn, hurt, injection, syringe, cloth, knitting). Next the student is asked if a word similar in meaning but not read (example: needle) was heard. There are twenty-four 15-word lists that can be used in this exercise. The exercise illustrates for students the natural tendency to fill-in words and make assumptions when listening. Awareness of this tendency can increase listener attentiveness to exactly what is being said.

Finally, the instructor reads out a description of a ordering procedure or any other real-world business procedure and without taking notes, each student is to listen carefully, ask questions, and generally practice what he believes to be good listening skills. Next, each student writes down what was heard, and then all students share with the class what they believe they heard. By comparing each other's comprehension of the business procedures, students are made more aware of their tendency to overlook items presented while including items that were not presented.

Having been made aware of the work that is involved in effective listening, students are then presented the materials discussed in the first two sections. After learning about barriers to listening and how to overcome them, they again go through the second two exercises to see if their listening effectiveness has improved.

\section{Conclusions}

Listening is a skill that has been identified as being of major importance in the workplace. It is also a skill that can be learned and improved. By providing students with increased understanding of the potential barriers to effective communication and how to combat them, we can improve the quality of their work and their organizational experiences.

\section{References}

HighGain (June, 2000). Not Listening is an American Thing, Sssh! Listen Up!, Retrieved December 6, 2001 from the World Wide Web http://www.highgain.com/newsletter/back-1ssues/

Hutinski, Z., Vrcek, N., Bubas, G. (2001). Communication in Complex Information System Development Projects, Proceedings of the 2001 Informing Science Conference, Krakow, Poland, Retrieved January 4, 2002 from the World Wide Web http://ecommerce.lebow.drexel.edu/eli

Janczewski, L. (2001). Communication Skills for Information Systems Students, Proceedings of the 2001 Informing Science Conference, Krakow, Poland. Retrieved January 4, 2002 from the World Wide Web http:t/ecommerce.lebow.drexel.edu/elit

Krisco, K. (1997). Leadership and the Art of Conversation: Conversation as a Management Tool. Rocklin CA: Prima Publishing.

Locker, K. \& Kaczmarek, S. (2001). Business Communication: Building Critical Skills, Boston: McGraw-Hill Irwin.

Ober, S. (2001). Contemporary Business Communication. Boston: Houghton Mifflin Company. 
Teaching Effective Listening Skills

Roediger, H. and McDermott, K. (1995). Creating False Memories: Remembering Words Not Presented in Lists, Journal of Experimental Psychology, 21, 4, 803-814.

Vitiello, J. (2001). Fast Track into Management, Computerworld, July 16, 42-43.

\section{Biography}

Janette Moody, Ph.D., is Associate Professor at The Citadel, teaching in the areas of information systems and accounting. Her research interests include the service orientation of IT professionals, and communication issues in IT projects. 